\title{
GROWTH AND NODULATION IMPROVEMENT OF PEANUT BY RHIZOBIAL AND CYANOBACTERIAL APPLICATIONS.
}

(Received: 20.7.2009)

\author{
By \\ K. Talaat*, A.A. Ragab,* W.D. Saleh and A.M. Higazy \\ Department of Agricultural Microbiology, Faculty of Agriculture, Cairo University, Giza, Egypt. \\ * Department of Microbiology, A.R.C., Giza, Egypt.
}

\begin{abstract}
A pot experiment was conducted in the greenhouse of the Agricultural Recearch Center (ARC) to evaluate the response of two cultivars of peanut to rhizobial inoculation and cyanobacterial application. The results indicated that the biomass of peanut plants, significantly increased due to rhizobia inoculation with strains Kh8 and Kh11. Soil treatment with some cyanobacterial filtrates enhanced growth and nodulation of the legume plant. Plants of peanut $\mathrm{cv}$. Georgia exhibited higher dry weights of both roots (1.93 mg plant ${ }^{-1}$ ) and shoots $\left(6.43 \mathrm{mg} \mathrm{plant}^{-1}\right)$, as well as better nodulation parameters ( 241 nodules plant ${ }^{-1}$ of $0.51 \mathrm{mg}$ ). In addition, the data revealed that $\mathrm{N}$-content of peanut for both tested cultivars increased as a result of mixed rihzobial inoculation with $\mathrm{Kh} 8$ and Kh11 and cyonobacterial treatments. In this respect, $146 \mathrm{mg} \mathrm{N} /$ plant and $99 \mathrm{mg} \mathrm{N} /$ plant were obtained for cv. Giza 5, respectively. It is, therefore, suggested that in addition to rhizobial inoculation, the treatment with cyanobacterial filtrates as a source of phytohormones led to significant enhancement of both growth and nodulation of peanut.
\end{abstract}

Key words: biofertilization, cyanobacteria, legumes, peanut, rhizobia.

\section{INTRODUCTION}

Peanut (Arachis hypogaea L.) is considered one of the most important oil seed leguminous crops and cultivated regularly in sandy soils in Egypt.

Several reports described the potential uses of plant associated bacteria as agents stimulating plant growth and managing soil and plant health (Hallman et al., 1997 and Sturz et al., 2000). Plant growth promoting rhizobacteria "PGPR" (Bashan and Holguin, 1998) are associated with many, if not all, plant species and are commonly present in many environments. Consequently, intimate associations between bacteria and a host plant can be formed without harming the plant (Klopper and Beauchamp,1992, and Lodewycky et al., 2002).

Co-inoculation of legumes with PGPR and Rhizobium has recently received increasing attention and can produce plant growth regulators. Dual inoculation with both symbiotic and asymbiotic bacteria may increase nodulation through a variety of mechanisms. For example, PGPR were reported to colonize plant root surfaces, produce phytoalexin, antibiotics and siderophores (Parmer and Dadarwal, 1999 and Postma et al., 2003). Additionally, dual inoculation with Rhizobium and PGPR can stimulate or inhibit nodule formation and growth in a given symbiotic relationship, depending upon the nature and concentration of secondary metabolites released by the non-rhizobial PGPR.

On the other hand, cyanobacteria were reported to produce several bioactive substances that affect plant growth, such substances may include gibberellic acid (GA), indole acetic acid (IAA) and abscisic acid, ABA (Zaccaro de Mule et al., 1991 and Yavorska and Dragovoz, 2001).

This study was conducted to point out the influence of single and dual rhizobial inoculation of peanut (Arachis hypogaea L.), cvs. Georgia and Giza 5, with KH 8 and KH 11 strains. It has been done in presence of cyanobacteria. In this respect, plant parameters and nodulation were evaluated at the end of the experiments.

\section{MATERIALS AND METHODS}

\subsection{Host plants}

Seeds of peanut (Arachis hypogaea) cvs. Giza 5 and Georgia were kindly provided by Legume Crops Department ARC., Giza. Each cultivar is recommended for cultivation in its representative region. Seeds were selected to be similar in size and weight to the nearest $10 \mathrm{mg}$. 


\subsection{Rhizobial strains}

Twelve isolates of Rhizobium sp. specific to peanut were obtained from root nodules of peanut cultivated at the ARC Research Station in Noubaria and Badr city. Rhizobial isolates were maintained on yeast extract mannitol (YEM) agar medium (Somosegaran and Hoben, 1994), and were tested for their effectiveness applying plant infection technique (Vincent, 1970).

\subsection{Cyanobacterial strains}

Three filamentous heterocystous cyanobacterial strains belonging to the genera Anabaena, Nostoc and Calothrix were kindly obtained from the Department of Agricultural Microbiology, Fac. Agric., Cairo University (Higazy et al., 2004) and were applied in some treatments. All cultures were maintained on Allen and Arnon medium (Allen and Arnon, 1955) under phototrophic growth conditions. Stock cultures were grown under continuous illumination, with Philips florescent white lamps at a relatively low light intensity (400-500 lux) and incubated at $30^{\circ} \mathrm{C}$. $\mathrm{GA}_{3}$, IAA and ABA were determined in culture filtrates of these strains by Gas Liquid Chromatography (Bye Unicam pro-GLC) according to the method described by Vogel (1975) in the Central Laboratory, Faculty of Agriculture, Cairo University. Data were expressed as quantity of phytohormons as g 100 $\mathrm{ml}^{-1}$ culture filtrate ${ }^{-1}$.

\subsection{Preparation of cyanobacterial filtrate}

A filtrate mixture of 1:1:1 was prepared from a 30-day old cultures of either Anbaena, Nostoc or Calothrix. Fifty $\mathrm{ml}$ of this mixture were added on soil surface before and after 15 days of seed germination.

\subsection{Soil analysis}

The soil used in pot experiment was collected from a new reclaimed region at Ismailia Governorate. The soil properties were determined according to Piper (1950) and Jackson (1973) and are presented in Table (1). Soil samples were taken from the top 0-30 $\mathrm{cm}$, air dried and distributed in plastic pots $(\varphi 30 \mathrm{~cm})$ at the rate of $10 \mathrm{~kg} \operatorname{pot}^{-1}$.

\section{6. Preparation of rhizobial inocula}

Two hundred $\mathrm{ml}$ of YEM liquid medium (Vincent, 1970), distributed in $500 \mathrm{ml}$ conical flasks, were inoculated with Rhizobium sp. strains and incubated on a rotary shaker for 5-7 days at $28^{\circ} \mathrm{C}$. In the greenhouse experiment, each seed was inoculated with $1 \mathrm{ml}$ (ca. $10^{9}$ cells ) from the rhizobial culture.

\subsection{Experimentation \\ 2.7.1 Plant infection experiment}

Two plant infection technique experiments were made using Linard jars system (Vincent, 1970) to select the potent strains that interacted with peanut cvs. Georgia and Giza 5. At the end of the experiment, fresh and dry weights of both shoots and roots as well as nodulation parameters were determined.

\subsubsection{Pot experiment}

Pots of $30 \mathrm{~cm}$ diameter were filled with $10 \mathrm{~kg}$ soil portions. In all treatments, soil was amended with ammonium sulphate $\left(\mathrm{NH}_{4}\right)_{2} \mathrm{So}_{4}(20.5 \% \mathrm{~N})$ at the rate of $25 \mathrm{~kg} \mathrm{fed}^{-1}$ as a starter dose before sowing. Phosphate fertilizer was incorporated into soil at the rate of $200 \mathrm{~kg} \mathrm{fed}^{-1}$ as super phosphate $\left(15.5 \% \mathrm{P}_{2} \mathrm{O}_{5}\right)$. Seeds of peanut were sown at the rate of 5 seeds pot $^{-1}$. Three replicates were used for each treatment. After 45 days of planting, plants were uprooted and determined for shoot and root dry weights $\left(\mathrm{mg} \mathrm{plant}^{-1}\right)$, after drying at $70^{\circ} \mathrm{C}$, shoot $\mathrm{N}$-content as well as the number and biomass (mg plant ${ }^{-1}$ ) of nodules were also determined.

Nine treatments were applied as follows:

1- Control 1 (without $\mathrm{N}$ fertilization or inoculation),

2- Control 2 (recommended dose of $\mathrm{N}$ without inoculation),

3- Rhizo inoculation with strain $\mathrm{Kh} 8$.

4- Rhizo inoculation with strain $\mathrm{Kh} 8+$ cyano,

5- Rhizo inoculation with strain Kh 11.

6- Rhizo inoculation with strain Kh $11+$

Cyano.

7- Rhizo inoculation with strain $\mathrm{kh} 8+\mathrm{K} 11$.

8- Rhizo inoculation with strain kh8 + k $11+$

Cyano.

9- Cyano treatment only.

Table (1): Mechanical and physicochemical properties of Ismailia soil used in the greenhouse experiments.

\begin{tabular}{|c|c|}
\hline Properties & Values \\
\hline Coars sand (\%) & 51.14 \\
\hline Fine sand $(\%)$ & 45.14 \\
\hline Silt (\%) & 1.30 \\
\hline Clay $(\%)$ & 2.20 \\
\hline Textural class & Sandy \\
\hline Organic-carbon (\%) & 0.11 \\
\hline Organic matter (\%) & 0.19 \\
\hline Water holding capacity & 16.11 \\
\hline $\mathrm{pH}$ & 7.91 \\
\hline E.C. $\left(\mathrm{d} \mathrm{sm}^{-1}\right)$ & 0.30 \\
\hline \multicolumn{2}{|l|}{ Soluble cations $(\mathrm{meq} / \mathrm{l})$ : } \\
\hline $\mathrm{Ca}^{++}$ & 0.72 \\
\hline $\mathrm{Mg}^{++}$ & 0.50 \\
\hline $\mathrm{Na}^{++}$ & 1.60 \\
\hline $\mathrm{K}^{++}$ & 0.14 \\
\hline \multicolumn{2}{|l|}{ Soluble anions (meq/l): } \\
\hline $\mathrm{HCO}_{3}^{-}$ & 1.77 \\
\hline $\mathrm{CL}^{-}$ & 0.60 \\
\hline $\mathrm{SO}_{4}{ }^{=}$ & 0.59 \\
\hline $\mathrm{CO}_{3}=$ & 0.00 \\
\hline
\end{tabular}




\section{RESULTS AND DISCUSSION}

\subsection{Screening of rhizobia isolates for} inoculation experiments

Twelve strains of Rhizobium. sp. were screened for their effectiveness with two peanut cultivars. The data in Table (2) indicated that the highest nodule numbers of 228 and 241 plant $^{-1}$, nodule dry weights of 0.44 and $0.51 \mathrm{mg}$ plant $^{-1}$ were obtained for peanut cv. Georgia when being inoculated with Kh8 and Kh 11, strains respectively. Table (3) presents the highest nodule numbers of 252 and 266 plant $^{-1}$, nodule dry weights of 0.51 and $1.1 \mathrm{mg}$ plant $^{-1}$ were obtained for peanut cv. Giza 5 after being inoculated with $\mathrm{Kh} 8$ and $\mathrm{Kh} \mathrm{11,} \mathrm{strains} \mathrm{in}$ that order. Therefore, the strains Kh8 and Kh11 proved to be the most efficient and subsequently were selected for the pot experiment.

3.2 Growth and nodulation of peanut cv. Georgia due to rhizobial inoculation and cyanobacteria application.

Data in Table (4) indicate that significant increases, in response to the various treatments, were observed. For example, the highest increases in shoots nitrogen content, roots dry weight and nodules dry weight were $64.2,666$ and $920 \%$ over their corresponding controls, respectively in treatments 9,8 and 8 , in that order. Also, it is an interesting observation that when cyanobacterial filtrate was introduced with either $\mathrm{Kh} 8$ or Kh 11, individually or in mixture, peanut plants exhibited higher values in their growth and nodulation parameters. Their shoot nitrogen content, root dry weight and nodule dry weight reached $99 \mathrm{mg}$ plant $^{-1}, 4.6 \mathrm{mg}$ plant $^{-1}$ and $0.51 \mathrm{mg}$ nodule ${ }^{-1}$, respectively.

\subsection{Influence of rhizobial inoculation and cyanobacterial application on the growth and nodulation parameters of peanut $\mathrm{cv}$. Giza 5.}

Similar results were found with peanut cv. Giza 5 and demonstrated in Table (5). It could be concluded that the response of peanut plants to rhizobial inoculation was much better when cyanobacterial filtrates were introduced. For instance, the highest records of shoot nitrogen content, root dry weight and nodule dry weight were $148.15 \mathrm{mg}_{\text {plant }}{ }^{-1}, 1.79 \mathrm{mg}$ plant $^{-1}$ and 0.49 $\mathrm{mg}$ nodule $^{-1}$, respectively, were obtained in treatments 9,3 and 8 , in that order.

\subsection{Cyanobacteria growth promoting regulators}

The ability to produce some growth promoting substances, i.e., phytohormones was examined for all the tested cyanobacterial strains. Table (6) shows that Nostoc sp produced $0.3012 \mathrm{~g}$ indole acetic acid (IAA) $100 \mathrm{ml}^{-1}$ culture filtrate ${ }^{-1}$. While, the same strain was able to excrete $0.8005 \mathrm{~g}$ abscisic acid (ABA) $100 \mathrm{ml}^{-1}$ culture filtrate $\mathrm{e}^{-1}$. Also, Anabaena sp did produce $3.010 \mathrm{~g}$ gibberellic acid $\left(\mathrm{GA}_{3}\right) 100 \mathrm{ml}^{-1}$ culture filtrate ${ }^{-1}$.

The previous observations may indicate that both rhizobial inoculation and cyanobacteria application increased the root, shoot and nodule dry weights. In this respect, Dey et al. (2004) reported that both growth and yield of peanut (Arachis hypogaea L.) were enhanced by the application of plant growth-promoting rhizobacteria.

Nasef et al . (2006) studied the effect of foliar spray with boron and Rhizobium inoculation on peanut plants grown in sandy soil. They found that boron foliar spray at $220 \mathrm{ppm}$ in combination with seed inoculation with Rhizobium enhanced plant growth and improved peanut yield and its components. Cyanobacteria were reported to have many useful applications such as improving the growth, development and biofertitization of many plants (Malliga and Subramaniam, 2002), production of plant growth promoting substances like IAA and ABA (Yavorska and Dragovoz, 2001). Therefore, it is not surprising that the application of Nostoc, Anabaena and Calothrix as a source of phytohormones in this study, led to significant increases in peanut growth and nodulation parameters.

Regarding the plant growth promoting rhizobacteria (PGPR) and stimulation of legume - rhizobia symbioses, it is evident that the most commonly implicated mode of action is the stimulation of root growth (Molla et al., 2001 and Vessey and Buss, 2002), which may provide more sites for infection and nodulation. Some PGPR may increase the avilabilaty of nutrients for the plant in the rizosphere (Rodriguez and Frage, 1999) and increase root surface area (Antoun et al., 1998). 
Table (2): Influence of inoculation with several rhizobial isolates on the growth and nodulation of 45-day old plants of peanut cv. Georgea.

\begin{tabular}{|c|c|c|c|c|c|c|c|}
\hline \multirow{3}{*}{ Treatments } & \multicolumn{2}{|c|}{ Shoots } & \multicolumn{2}{|c|}{ Roots } & \multicolumn{3}{|c|}{ Nodules } \\
\hline & FW* & DW & FW* & DW & No. & FW & DW \\
\hline & \multicolumn{2}{|c|}{$\left(\mathrm{mg} \mathrm{plant}^{-1}\right)$} & \multicolumn{2}{|c|}{$\left(\mathrm{mg} \mathrm{plant}^{-1}\right)$} & \multicolumn{3}{|c|}{$\left(\right.$ mg nodules $\left.^{-1}\right)$} \\
\hline Control & 20.13 & 4.73 & 10.50 & 1.30 & 88 & 0.10 & 0.20 \\
\hline $\mathrm{Kh}_{1}$ & 26.53 & 6.43 & 15.96 & 1.93 & 146 & 1.43 & 0.29 \\
\hline $\mathrm{Kh}_{2}$ & 18.63 & 4.60 & 13.33 & 1.26 & 98 & 0.73 & 0.18 \\
\hline $\mathrm{Kh}_{3}$ & 22.83 & 4.03 & 14.43 & 1.43 & 181 & 0.57 & 0.37 \\
\hline $\mathrm{Kh}_{4}$ & 23.16 & 5.60 & 16.60 & 1.60 & 144 & 1.20 & 0.31 \\
\hline $\mathrm{Kh}_{6}$ & 20.16 & 4.73 & 12.40 & 1.31 & 153 & 0.50 & 0.28 \\
\hline $\mathrm{Kh}_{7}$ & 23.33 & 5.27 & 14.10 & 1.33 & 228 & 1.23 & 0.42 \\
\hline $\mathrm{Kh}_{8}$ & 23.56 & 5.66 & 15.40 & 1.42 & 228 & 2.36 & 0.44 \\
\hline $\mathrm{Kh}_{9}$ & 26.37 & 6.20 & 14.63 & 1.60 & 165 & 1.63 & 0.36 \\
\hline $\mathrm{Kh}_{10}$ & 17.86 & 4.06 & 19.66 & 0.86 & 163 & 1.26 & 0.27 \\
\hline $\mathrm{Kh}_{11}$ & 16.14 & 5.53 & 16.10 & 1.65 & 241 & 2.13 & 0.51 \\
\hline $\mathrm{Kh}_{12}$ & 25.23 & 5.93 & 14.20 & 1.61 & 197 & 1.50 & 0.40 \\
\hline $\mathrm{Kh}_{14}$ & 21.33 & 4.83 & 13.07 & 1.33 & 209 & 2.03 & 0.44 \\
\hline L.S.D. & 2.91 & 0.69 & 1.80 & 0.23 & 37.4 & 0.34 & 0.06 \\
\hline
\end{tabular}

Fw,fresh weight; Dw, dry weight; No., numbers.

Table (3): Growth and nodulation parameters of 45-day old plants of peanut cv. Giza 5 after inoculation with several strains of rhizobia.

\begin{tabular}{|c|c|c|c|c|c|c|c|}
\hline \multirow{2}{*}{ Treatments } & \multicolumn{2}{|c|}{ Shoots } & \multicolumn{2}{|c|}{ Roots } & \multicolumn{3}{|c|}{ Nodules } \\
\hline & $\mathrm{FW}^{*}$ & DW & $\mathbf{F W}^{*}$ & DW & No. & FW & DW \\
\hline & \multicolumn{2}{|c|}{$\left(\mathrm{mg} \mathrm{plant}^{-1}\right)$} & \multicolumn{2}{|c|}{$\left(\mathrm{mg} \mathrm{plant}^{-1}\right)$} & \multicolumn{3}{|c|}{$\left(\right.$ mg nodules $\left.^{-1}\right)$} \\
\hline Control & 15.3 & 4.3 & 10.1 & 1.6 & 11 & 0.10 & 0.01 \\
\hline $\mathrm{Kh}_{1}$ & 27.8 & 6.8 & 16.3 & 1.6 & 176 & 1.50 & 0.29 \\
\hline $\mathrm{Kh}_{2}$ & 26.0 & 6.5 & 16.9 & 1.4 & 209 & 1.40 & 0.36 \\
\hline $\mathrm{Kh}_{3}$ & 21.0 & 4.7 & 10.4 & 0.9 & 142 & 1.40 & 0.32 \\
\hline $\mathrm{Kh}_{4}$ & 23.2 & 5.4 & 19.3 & 2.1 & 81 & 0.50 & 0.20 \\
\hline $\mathrm{Kh}_{6}$ & 18.1 & 4.3 & 12.1 & 1.1 & 169 & 0.70 & 0.31 \\
\hline $\mathrm{Kh}_{7}$ & 23.7 & 5.5 & 13.4 & 1.2 & 165 & 1.70 & 0.46 \\
\hline $\mathrm{Kh}_{8}$ & 20.9 & 4.9 & 19.2 & 1.3 & 252 & 2.25 & 0.51 \\
\hline $\mathrm{Kh}_{9}$ & 22.2 & 5.3 & 16.3 & 1.21 & 108 & 1.30 & 0.22 \\
\hline $\mathrm{Kh}_{10}$ & 19.4 & 4.3 & 9.1 & 0.7 & 65 & 0.70 & 0.13 \\
\hline $\mathrm{Kh}_{11}$ & 22.2 & 5.1 & 18.7 & 1.9 & 266 & 2.55 & 1.10 \\
\hline $\mathrm{Kh}_{12}$ & 19.4 & 4.5 & 14.4 & 1.7 & 198 & 1.60 & 0.38 \\
\hline $\mathrm{Kh}_{14}$ & 18.6 & 4.2 & 9.9 & 0.9 & 196 & 2.10 & 0.40 \\
\hline L.S.D. & 2.52 & 0.71 & 1.80 & 0.33 & 31.9 & 0.43 & 0.053 \\
\hline
\end{tabular}

Fw,fresh weight; Dw, dry weight; No., numbers 
Table (4): Effect of rhizobial biofertilization and cyanobacterial application on growth and nodulation of 45-day old plants of peanut of cv. Georgea

\begin{tabular}{|c|c|c|c|c|c|c|c|c|}
\hline \multirow{3}{*}{ Treatments } & \multicolumn{3}{|c|}{ Shoots } & \multicolumn{2}{|c|}{ Roots } & \multicolumn{2}{|c|}{ Nodules } & \multirow[b]{2}{*}{ DW } \\
\hline & $\mathbf{F W}^{*}$ & DW & $\mathbf{N}$ & FW & DW & No. & FW & \\
\hline & \multicolumn{3}{|c|}{ mg/plant } & \multicolumn{2}{|c|}{ mg/plant } & \multicolumn{3}{|c|}{ mg/nodules } \\
\hline 1. Control (1) & 32.30 & 8.6 & 62.20 & 1.50 & 0.60 & 11 & 0.10 & 0.05 \\
\hline 2. Control (2) & 19.93 & 5.0 & 54.03 & 1.16 & 0.93 & 4 & 0.10 & 0.04 \\
\hline 3. Kh8 & 27.60 & 7.4 & 53.90 & 13.80 & 1.03 & 110 & 0.87 & 0.20 \\
\hline 4. Kh8+Cyano & 27.70 & 7.4 & 69.70 & 11.90 & 2.60 & 127 & 1.66 & 0.29 \\
\hline $5 . \mathrm{Kh} 11$ & 25.80 & 6.1 & 67.63 & 15.20 & 1.30 & 147 & 1.18 & 0.20 \\
\hline 6. Kh11+ Cyano & 24.13 & 7.1 & 85.16 & 17.90 & 1.70 & 166 & 1.38 & 0.25 \\
\hline 7. Kh8+Kh11 & 26.70 & 6.8 & 84.00 & 14.50 & 1.80 & 174 & 1.17 & 0.23 \\
\hline $\begin{array}{l}\text { 8. Kh8+Kh11+ } \\
\text { Cyano }\end{array}$ & 36.13 & 8.7 & 99.00 & 21.90 & 4.60 & 181 & 1.66 & 0.51 \\
\hline 9. Cyano only & 41.90 & 10.7 & 102.10 & 21.70 & 1.90 & 117 & 1.25 & 0.45 \\
\hline L.S.D. $\quad 0.05 \%$ & 4.47 & 1.10 & 9.72 & 1.84 & 0.78 & 17.49 & 0.145 & 0.052 \\
\hline
\end{tabular}

FWfresh weight; DW, dry weight; No., numbers, N, nitrogen content

Table (5): Growth and nodulation parameters of 45-day old plants of peanut cv. Giza 5 after biofertilization with different rhizobial strains and cyanobacteria application.

\begin{tabular}{|c|c|c|c|c|c|c|c|c|}
\hline \multirow{3}{*}{ Treatments } & \multicolumn{3}{|c|}{ Shoots } & \multicolumn{2}{|c|}{ Roots } & \multicolumn{2}{|c|}{ Nodules } & \multirow[b]{2}{*}{$D W$} \\
\hline & FW & $\overline{D W}$ & $\mathbf{N}$ & FW & DW & $\begin{array}{l}\mathbf{N} \\
\mathbf{0}\end{array}$ & $\bar{N}$ & \\
\hline & \multicolumn{3}{|c|}{ mg/plant } & \multicolumn{2}{|c|}{ mg/plant } & \multicolumn{3}{|c|}{ mg/nodules } \\
\hline 1. Control (1) & 22.33 & 6.2 & 67.5 & 10.5 & 0.97 & 23 & 0.20 & 0.02 \\
\hline 2. Control (2) & 17.50 & 5.1 & 52.6 & 9.1 & 0.83 & 6 & 0.10 & 0.07 \\
\hline 3. Kh8 & 22.30 & 6.2 & 67.5 & 10.5 & 1.97 & 33 & 1.20 & 0.09 \\
\hline 4. Kh8+Cyano & 23.70 & 5.4 & 130.9 & 12.7 & 1.50 & 150 & 1.40 & 0.31 \\
\hline 5. Kh11 & 26.50 & 4.9 & 107.7 & 10.4 & 1.13 & 118 & 1.27 & 0.31 \\
\hline 6. Kh11+ Cyano & 26.63 & 7.0 & 99.2 & 12.4 & 1.40 & 147 & 1.50 & 0.41 \\
\hline 7. Kh8+Kh11 & 19.96 & 4.3 & 12.6 & 9.8 & 1.13 & 191 & 1.63 & 0.38 \\
\hline $\begin{array}{l}\text { 8. Kh8+Kh11+ } \\
\text { Cyano }\end{array}$ & 20.10 & 4.4 & 146.1 & 16.5 & 1.10 & 219 & 1.33 & 0.49 \\
\hline 9. Cyano only & 25.20 & 5.4 & 148.2 & 11.9 & 1.10 & 155 & 1.34 & 0.45 \\
\hline L.S.D. $\quad 0.05 \%$ & 3.21 & 0.64 & 16.7 & 1.70 & 1.22 & 11.88 & 0.26 & 0.047 \\
\hline
\end{tabular}

* Fw,fresh weight; DW, dry weight; No., numbers, N, nitrogen content.

Table (6): Phytohormones composition in cyanobacterial cultures filtrates.

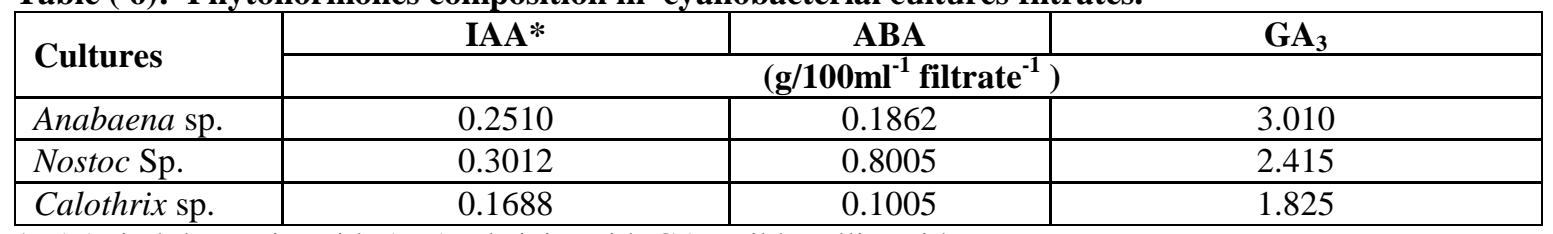

*,IAA, indole acetic acid; ABA, absicic acid; $\mathrm{GA}_{3}$, gibberallic acid. 


\section{REFERENCES}

Allen M. B. and Arnon D.I. (1955). Growth and nitrogen fixation by Anbabaena cylindrica. Plant Physiol., 30: 366-372.

Antoun H, Beauchamp C.J. , Goussard, N.; Chabot, R. and Lalande R.(1998). Potential of Rhizobium and Bradyrhizobium species as plant growth promoting rhizobacteria on non legumes: Effect on radishes ( Raphanus sativus L.) Plant Soil, 204: 57-67

Bashan Y. and Holguin G. (1998). Proposal for the division of plant growth promoting rhizobacteria into two classifications Biocontrol-PGPB (Plant GrowthPromoting Bacteria) and PGPR. Soil Biol. Biochem., 30: 1225-1228.

Dey R., Pal K. K., Bhatt D. M. and Chauhan S. M. (2004). Growth promotion and yield enhancement of peanut (Arachis hypogaea L.) by application of plant growthpromoting rhizobacteria. Microbiol. Res., 159: 371-394.

Hallman J., Quadt-Hallman A., Manafee W. F. and Kloepper J. W. (1997). Bacterial endophytes in agricultural crops. Can. J. Microbiol., 43: 895-914.

Higazy A., Refae R. I., El Sayeda A. Abdel-Aal and Awad A.A. (2004). Biodiversity of marine cyanobacteria in Soda lake, Egypt: 1. Isolation and taxonomic studies of some unicellular and filamentous cultures. Annals Agric. Sci., Ain Shams Univ., Cairo. 49(1): 19-40.

Jackson M. I. (1973). Soil Chemical Analysis. Constable and con. Ltd., London.

Klopper J. W. and Beauchamp C. J. (1992). A review of issues related to measuring colonization of plant roots by bacteria. Can. J. Microbiol., 38: 1219-1232.

Lodewycky C., Vangronsveld J., Proteous F., Moore E.R.B., Taghavi S., Mezgeay M. and Vander Lelie, D. (2002). Endophytic bacteria and their potential applications. Crit. Rev. Plant Sci., 21: 583-606.

Malliga P. and Subramaniam G. (2002). Cyanobacterial biofertilizer for sustainable agriculture. Bioinoculants for sustainable agriculture and forestry. Proceeding of National Symposium held on February 16, 18:99-106.

Molla A. H, Shamsuddin Z. H.; Halimi M. S; Morziah, M. and Puteh, A. B. (2001). Potential for enhancement of root growth and nodulation of soybean co-inoculated with Azospirillum and Bradyrhizobium in laboratory system . Soil Biol. Biochem., 33:457-463.

Nasef M.A., Badran N.M. and Abd El-Hamid A.F. (2006). Response of peanut to foliar spray with boron and /or Rhizobium inoculation. J. Appl. Sci. Res., 2 (12): 1330-1137.

Parmer N. and Dadarwal K. R. (1999). Stimulation of nitrogen fixation and induction of flavonoid-like compounds by rhizobacteria. J. Appl. Microbiol., 86: 3644.

Piper C. S. (1950). Soil and Plant Anaylsis. $1^{\text {st }}$ Ed. Interscience Publishers Inc., New York, pp. 30-229.

Postma J.,Montanari M. and Van den Boogert, P.H.J.F. (2003). Microbial enrichment to enhance the disease suppressive activity of compost. Eur. J. Soil. Biol., 39: 157163.

Rodriguez H. and Frage R. (1999). Phosphate solubilizing bacteria and their role in plant growth promotion. Biotechnol.Adv., 17: $319-319$.

Somosegaran P. and Hoben H. J. (1994). Handbook for Rhizobia: Methods in Legume Rhizobium technology. Springer, Berlin Heidelber New York. USA.

Sturz A. V., Christie, B. R. and Nowak J. (2000). Bacterial endophytes: Potential role in developing sustainable systems of crop production. Crit. Rev. Plant Sci., 19: 1-30.

Vessey J.K. and Buss, T.J.(2002). Bacillus cereus UW 85 inoculation effects on growth, nodulation and $\mathrm{N}$ accumulation in grain legumes. Controlled environment studies. Can. J. Plant Sci. 82: 282- 290.

Vincent J. M. (1970). A Manual for the Practical Study of the Root Nodule Bacteria. In: International Biological Programe handbook No.15. Blackwell Scientific Publication. Ltd., Oxford and Edinburgha, U.K.

Vogel A. I. (1975). A Text Book of Practical Organic Chemistry. 4Book Society and Longman Group Limited publishers, $3^{\text {rd }}$ ed., 969PP.

Yavorska V.K. and Dragovoz I.V. (2001). Cyanobacteria as a source of natural growth regulators-phytohormones. International Symbosium on Microalgae and Seaweeds products in Plant/Soil-System. Mosonmagy arovar, Hungary, June 20-22. 
Zaccaro de Mule M. C., Caire G.; Cano M. and Halperin, D. (1991). Bioactive compounds from Nostoc muscorum (Cyanobacteria) Cytobios. 66:169-172.

$$
\begin{aligned}
& \text { تحسين نمو وتعقيد الفول السوداني بالتلقيح بالريزوبيا والمعاملة بالسيانوبكتريا } \\
& \text { خديجة طلعت* ، عاطف عبد العزيز رجب* ، وليد ضياء الدين صالح و عزيز محم حجازى } \\
& \text { قسم الميكروبيولوجيا الزر اعية ـ كلبة الزراعة ـ جامعة القاهره }
\end{aligned}
$$

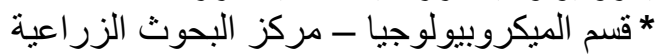

ملخص

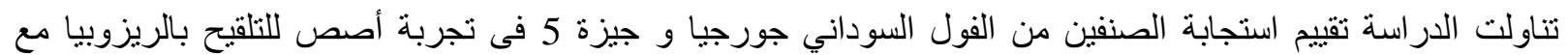

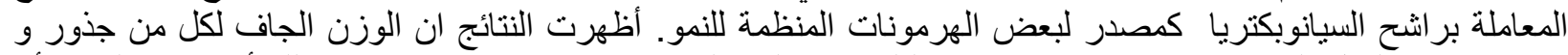
سيقان نباتات الفول السوداني قد زاد معنويا نتيجة التلقيح بسلالتى الريزوبيا

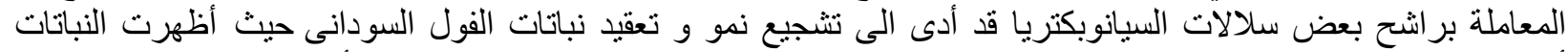

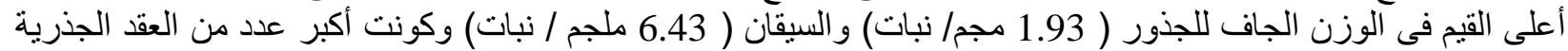

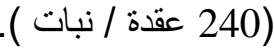
من جهة أخرى، أثنتت النتائج أن المحتوى النتروجينى لنباتات الفول السودانى للصنفين المختبرين زاد نتيجة التلقيح

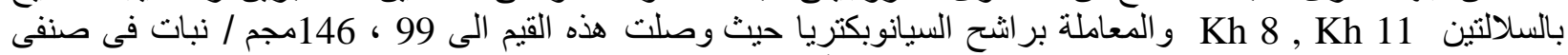

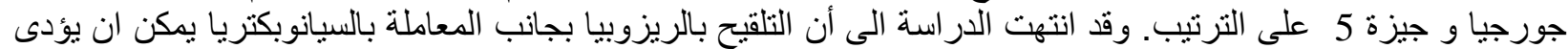
الى تحسين كل من نمو و تعقيد نباتات الفول السودانى.

المجلة العلمية لكلية الزراعة - جامعة القاهرة - المجلا (60) العدد الرابع (أكتوبر 2009 ) : 460-466. 